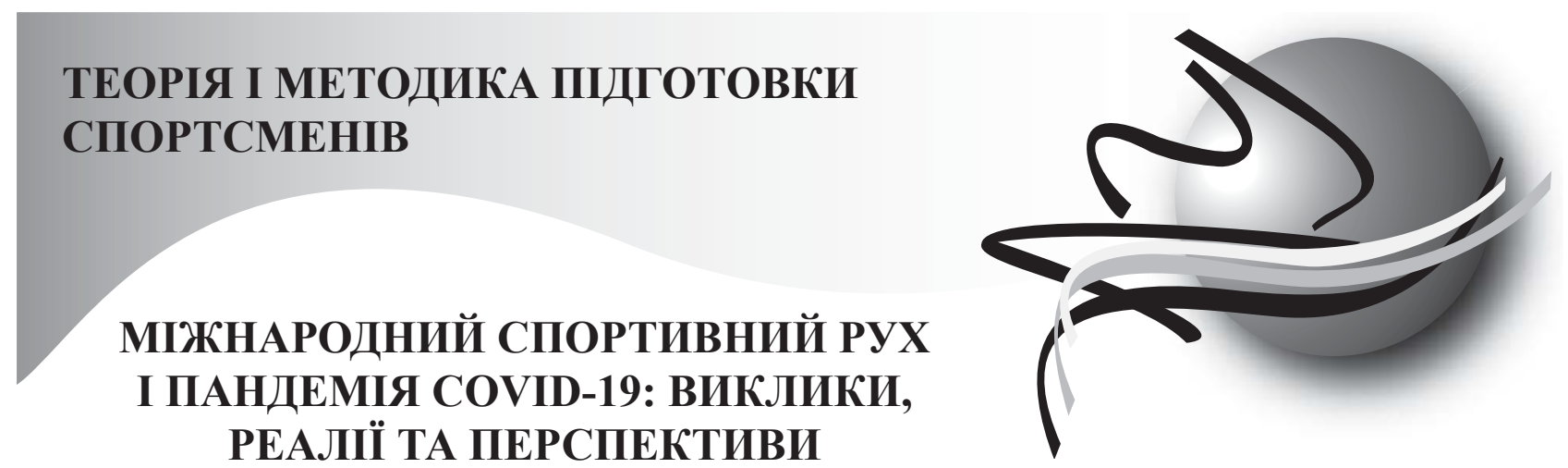

\author{
Пангелова Наталія, Рубан Владислав, Пангелов Борис \\ Університет Григорія Сковороди в Переяславі
}

\title{
DOI: 10.32540/2071-1476-2021-3-085
}

\section{Annotation}

Introduction. In today's world, sport has become an integral part of international relations. This is evidenced by a number of important international legal acts.

The coronavirus pandemic that swept the world in 2020 is comparable in scale to the effects of World War II in terms of its impact on the sports industry. The changes affected every aspect not only of sports competitions, but also of time, schedule, training format. Therefore, there is a need to analyze and summarize the data on global change that has affected most segments of the Olympic and sports movements.

Objective. Analysis, generalization, systematization of data of special scientific and methodical literature and electronic sources on the impact of the coronavirus pandemic on the current state and prospects of international sports and Olympic movements.

Research methods: theoretical analysis and generalization of data of scientific and methodical literature, normative documents, electronic sources; comparison method; method of system analysis.

Results. The most high-profile event in the sports world since the beginning of the pandemic was the postponement of the 2020 Olympic Games in Tokyo. On March 30, 2020, the International Olympic Committee announced that the Games will be held from July 23 to August 8, 2021. The European Football Championship was also postponed. As for the hostess of the 2020 Games, the Japanese authorities are gradually resuming the operation of sports facilities. The coronavirus pandemic has made significant adjustments to the life of the sports industry. Widespread isolation has accelerated the digitalization of the sports business and pushed organizers to implement projects based on online technologies.

Conclusions. The analysis of the conditions of functioning of the sphere of international sports and Olympic movements in the conditions of the global Covid-19 pandemic allowed to identify the following main tendencies: the sphere of sports and entertainment is increasingly focused on online formats; quarantined online practices will continue after the pandemic; among the main challenges in the sports industry are the decline in income of sports organizations, the omission of athletes throughout the season, as well as the loss of financial benefits and opportunities to train and compete, exacerbation of unemployment.

Key words: international sport, Covid-19 pandemic, challenges, realities, prospects.

\section{Анотація}

Вступ. У сучасному світі спорт став невід'ємною частиною міжнародних відносин. Про це свідчить ряд найважливіших міжнародно-правових актів.

Пандемія коронавірусу, яка охопила світ у 2020 році, за масштабами впливу на індустрію спорту порівняна хіба що із наслідками Другої Світової війни. Зміни торкнулись кожного аспекту не тільки спортивних зма-

(C) Пангелова Н., Рубан В.,

Пангелов Б., 2021 
гань, але й часу, розкладу, формату тренувань. У зв'язку з цим виникає необхідність в аналізі та узагальненні даних щодо глобальних змін, які вібулися у більшості сегментів олімпійського та спортивного рухів.

Мета. Аналіз, узагальнення, систематизація даних спеціальної науково-методичної літератури та електронних джерел щодо впливу пандемії коронавірусу на сучасний стан і перспективу розвитку міжнародного спортивного та олімпійського рухів

Методи дослідження: теоретичний аналіз та узагальнення даних науково-методичної літератури, нормативних документів, електронних джерел; метод порівняння; метод системного аналізу.

Результати. Найгучнішою подією в спортивному світі з початку пандемії стало перенесення на наступний рік Олімпійських ігор 2020 в Токіо. 30 березня 2020 року Міжнародний олімпійський комітет оголосив, що ігри пройдуть з 23 липня по 8 серпня 2021 року. Відтермінованим виявився і чемпіонат Свропи з футболу. Що стосується безпосередньо господарки Ігор 2020, то влада Японії поступово відновлює роботу спортивних об'єктів. Пандемія коронавируса внесла істотні корективи в життя спортивної індустрії. Повсюдна ізоляція прискорила цифровізацію спортивного бізнесу і підштовхнула організаторів до реалізації проектів, заснованих на онлайн-технологіях.

Висновки. Аналіз умов функціонування сфери міжнародного спортивного та олімпійського рухів в умовах світової пандемії Covid-19 дозволив визначити такі основні тенденції: сфера спорту і розваг все більше орієнтується на онлайн-формати; діючі в період карантину онлайн-практики продовжать діяти і після закінчення пандемії; серед основних викликів у спортивній індустрії можна відзначити падіння доходів спортивних організацій, пропуск спортсменами цілого сезону, а також втрату фінансових вигод і можливості тренуватися і конкурувати, загострення проблеми безробіття.

Ключові слова: міжнародний спорт, пандемія Covid-19, виклики, реалії, перспективи.

\section{Аннотация}

Введение. В современном мире спорт стал неотъемлемой частью международных отношений. Об этом свидетельствует ряд важнейших международно-правовых актов.

Пандемия коронавируса, которая охватила мир в 2020 году, по масштабам влияния на индустрию спорта сравнима разве что с последствиями Второй мировой войны. Изменения коснулись каждого аспекта не только спортивных соревнований, но и времени, расписания, формата тренировок. В связи с этим возникает необходимость в анализе и обобщении данных по глобальным изменениям, которые коснулись большинства сегментов олимпийского и спортивного движения.

Цель. Анализ, обобщение, систематизация данных специальной научно-методической литературы и электронных источников о влиянии пандемии коронавируса на современное состояние и перспективу развития международного спортивного и олимпийского движения

Методы исследования: теоретический анализ и обобщение данных научно-методической литературы, нормативных документов, электронных источников; метод сравнения; метод системного анализа.

Результаты. Самым громким событием в спортивном мире с начала пандемии стал перенос на следующий год Олимпийских игр 2020 в Токио. 30 марта 2020 Международный олимпийский комитет объявил, что игры пройдут с 23 июля по 8 августа 2021 года. Отсроченным оказался и чемпионат Европы по футболу. Что касается непосредственно хозяйки Игр 2020, то власти Японии постепенно восстанавливают работу спортивных объектов. Пандемия коронавируса внесла существенные коррективы в жизнь спортивной индустрии. Повсеместная изоляция ускорила цифровизацию спортивного бизнеса и подтолкнула организаторов к реализации проектов, основанных на онлайн-технологиях.

Выводы. Анализ условий функционирования сферы международного спортивного и олимпийского движения в условиях мировой пандемии Covid-19 позволил определить следующие основные тенденции: сфера спорта и развлечений все больше ориентируется на онлайн-форматы; действующие в период карантина онлайн-практики продолжат существовать и после окончания пандемии; среди основных вызовов в спортивной индустрии можно отметить падение доходов спортивных организаций, пропуск спортсменами целого сезона, а также потерю финансовых вознаграждений, возможности тренироваться и принимать участие в соревнованиях, обострение проблемы безработицы.

Ключевые слова: международный спорт, пандемия Covid-19, вызовы, реалии, перспективы.

Вступ. У сучасному світі спорт став невід'ємною частиною міжнародних відносин. Про це свідчить ряд найважливіших міжнародно-правових актів: план дій ЮНЕСКО щодо зміцнення правопорядку в спорті і забезпечення його загальнодоступності,
Резолюція Ради з прав людини $\mathrm{OOH}$ «Заохочення прав людини через спорт і ідеали Олімпійського руху», Заключний акт Наради

(C) Пангелова Н., Рубан В., Пангелов Б., 2021 
з безпеки і співробітництва в Свропі зі згадуванням про найважливішу роль спорту у формуванні безпеки $[3,7,12,15]$.

Пандемія коронавірусу, яка охопила світ у 2020 році, за масштабами впливу на індустрію спорту порівняна хіба що із наслідками Другої Світової війни. Зміни торкнулись кожного аспекту не тільки спортивних змагань, але й часу, розкладу, формату тренувань. У зв'язку з цим виникає необхідність в аналізі та узагальненні даних щодо глобальних змін, які торкнулися більшості сегментів олімпійського та спортивного рухів.

Так, спалах коронавірусу змусив призупинити проведення світових спортивних змагань. У рік, коли чемпіонат Свропи з футболу повинен був відбутися в 12 європейських країнах (червень - липень), а Олімпійські ігри в Токіо заплановані на липень - серпень 2020 року, спортивний календар був повністю переглянутий. Деякі змагання були скасовані, другі - перенесені в інші міста або відкладені на невизначений термін, треті - проводилися без глядачів або $з$ обмеженням за кількістю відвідувачів [6, 18].

Пандемія посіяла в світовому спорті справжню паніку. Організатори змагань не були готові брати на себе відповідальність і чекали вказівок - від національних урядів або від Всесвітньої організації охорони здоров'я (ВОО3).

Отже, в умовах коронавірусу про проведення масових заходів у 2020 році не йшлося. Саме у розпал пандемії повинні були відбутися Ігри XXXII Олімпіади у Токіо, які були заплановані на кінець липня. Час проведення змагань довелося перенести, а сама Японія втратила близько 12 млрд. доларів.

Руйнація графіків проведення торкнулася й інших великих змагань, - від Гельських ігор і Чемпіонату світу 3 хокею до Європейської універсіади $[13,14]$.

(C) Пангелова Н., Рубан В., Пангелов Б., 2021
Друга суттєва зміна, яка відбулася після перенесення проведення значущих заходів - це перехід в онлайн - режим. Спортивній інфраструктурі довелося у стислі терміни докорінно змінювати власну форму і зміст. Перехід в онлайн сприяв масовому та інтенсивному розвитку інтернет-технологій. Особливо це стосується платформ і сервісів, які дозволяють спостерігати за змаганнями у віддаленому режимі. Онлайнформат приніс у світ спорту більше інтерактивності - сайти і платформи регулярно пропонують користувачам різноманітні акції і бонуси за перегляди та інші дії [1, 11, 19, 20].

Ключові інновації від переходу в онлайн - це підвищення якості трансляцій, впровадження повноцінних програм, розваг i аналітики, а також інтенсивна взаємодія з уболівальниками у соціальних мережах, інтенсивний розвиток медійних технологій.

Аналіз публікацій свідчить про те, що саме індустрія спорту у розвинутих країнах найбільше постраждала від коронавірусу. У багатьох країнах були розроблені комплексні заходи підтримки індустрії (відтермінування податкових платежів і мораторій на банкрутство; залучення інвестицій; розробка масштабних державних контрактів та ін.) [17, 20, 21].

Необхідно також зазначити, що обмежувальні заходи у зв'язку 3 пандемією COVID-19 призвели також до змін у звичній життєдіяльності людей, включаючи спорт і фізичну активність. Масовий спорт виявився найбільш чутливим до впливу COVID-19.

Однак, пандемія зачепила також професійний спорт i зацікавлених стейкхолдерів: спортсменів, тренерів, інструкторів, адміністративний персонал (співробітники спортивних організацій), волонтерів, посадових осіб, задіяних в змаганнях (судді, члени делегацій), підприємства, в особливості мікро- і малий бізнес (фітнес-клуби, тренажерні зали, роздрібні торговці, організатори заходів, маркетингові агентства, виробники спортивної продукції).

Щоб уявити економічні збитки, наведемо наступні дані: глобальна вартість індустрії спорту оцінюється в 756 млрд. доларів в річному вираженні. Орієнтовно 270 млрд. доларів (36\%) припадає на сектор рітейлу, 200 млрд. доларів (26\%) - на інфраструктуру, іжу, напої і спортивні ставки, 171 млрд. доларів (23\%) - на галузь професійного спорту і 115 млрд. доларів (15\%) - на збори клубів і тренажерних залів $[5,21,22]$.

Спорт являє собою істотний сектор в економіці регіонів світу та окремих країн. Наприклад, в країнах $\mathrm{CC}$ частка ВВП, пов'язана зі спортом, становить 279,7 млрд євро, що еквівалентно 2,12\% від загального ВВП ЄС. Кількість людей, задіяних у сфері спорту, налічує 5,67 млн осіб, що відповідає 2,72\% робочих місць в країнах ЄC (кожен 37-й працівник зайнятий у спортивній сфері) [20, 21].

Некомерційна організація «Європейська платформа 3 інновацій в області спорту» (European Platform for Sport Innovation, EPSI) виділяє ряд викликів, з якими зіткнулася європейська спортивна індустрія і які є притаманними для всіх регіонів світу [15]:

- Більшість спортивних організацій втратили прибутки, оскільки в умовах карантину неможливо було надавати громадянам спектр своїх послуг. При цьому, за часом це збіглося з періодом, коли розпочався сезон для більшості видів спорту, тобто: організація підготовки і проведення змагань, збір коштів за допомогою проведення турнірів, організація різних заходів, семінарів, тренувальних зборів.

- Спортсмени втратили цілий сезон i, як наслідок, - певні фінансові кошти, а також - тренерів і можливість брати участь у спортивних змаганнях. Для декого це 
означає втрату можливості підвищити свій статус і отримати фінансові кошти 3 приватних i державних джерел (на місцевому, регіональному та національному рівнях).

- Спортсмени не отримували фінансову підтримку (стипендіi) у зв'язку з падінням доходів спортивних організацій.

- Організації зазнавали труднощів 3 фінансами. У них, як i раніше, зберігалися зобов'язання за фіксованими платежами незалежно від втрати доходів.

- Загострилася проблема безробіття: звільнення співробітників, спортсменів, тренерів та інших працівників, особливо тих, чия заробітна плата залежала від вищезазначених джерел доходу.

- Організації втратили значну частину своєї неоплачуваної робочої сили, оскільки в період пандемії волонтери мають обмежену мобільність.

Таким чином, аналіз спеціальної літератури та електронних інформаційних джерел надав можливість 3'ясувати категорії викликів, які виникли у спортивному русі у 2020 році в зв'язку з пандемією. Але особливу зацікавленість викликає питання прогнозу та перспектив функціонування міжнародного спортивного та олімпійського рухів в нових умовах, що і обумовлює актуальність даного теоретичного дослідження.

Мета. Аналіз, узагальнення, систематизація даних спеціальної науково-методичної літератури та електронних джерел щодо впливу пандемії коронавірусу на сучасний стан і перспективу розвитку міжнародного спортивного та олімпійського рухів

Методи дослідження. Теоретичний аналіз та узагальнення даних науково-методичної літератури, нормативних документів, електронних джерел; метод порівняння; метод системного аналізу.

Результати дослідження та дискусія. Найгучнішою подією в спортивному світі 3 початку пандемії стало перенесення на наступний рік Олімпійських ігор 2020 в Токіо. 30 березня 2020 року Міжнародний олімпійський комітет оголосив, що ігри пройдуть 3 23 липня по 8 серпня 2021 року. При цьому, незважаючи на перенесення вони збережуть назву Токійської олімпіади 2020 року. Паралімпійські ігри пройдуть 3 24 серпня по 5 вересня 2021 року. Дати проведення були узгоджені під час телефонної розмови між президентом МОК Томасом Бахом, організаторами «Токіо 2020», урядом Японії і Міжнародним паралімпійським комітетом. «У нинішніх обставинах і на основі інформації, наданої ВОО3, президент МОК і прем'єр-міністр Японії прийшли до висновку, що 3 метою захисту здоров'я спортсменів, всіх учасників Олімпійських ігор і міжнародної спільноти Ігри XXXII Олімпіади в Токіо повинні бути перенесені на дату після 2020 року, але не пізніше літа 2021 року», - йдеться в заяві MOK $[6,16]$.

Перенесення заходу відбулися перший раз за 124-річну історію сучасних Олімпійських ігор. Хоча були випадки, коли олімпійські ігри не відбувались, але їх порядковий номер зберігався. Так, вони були повністю скасовані в 1916 році, а потім в 1940 і 1944 роках у зв'язку з Першою і Другою світовими війнами відповідно.[2, 9, 10].

Відтермінованим виявився i чемпіонат Європи 3 футболу. У березні Виконавчий комітет Союзу європейських футбольних асоціацій (УЄФА) за підсумками відеоконференції за участю президентів і генеральних секретарів всіх 55 національних асоціацій, представників Асоціації європейських клубів, організації «Європейські ліги» і профспілки гравців «FIFPro Europe» оголосив про перенесення флагманського турніру національних збірних Євро2020 , який планується провести в червні - липні 2021 року.
17 липня 2020 року, в перший день проведення виконавчого комітету, керівництво Союзу європейських футбольних асоціацій (УСФА) прийнло рішення про формат відновлення розіграшу Ліги чемпіонів і перенесення на наступний рік фінал турніру в Санкт-Петербурзі, а також підтвердило терміни СВРО-2020 i список міст, які прийматимуть ігри турніру.

Розпочатий процес повернення великого спорту після «коронавірусних канікул» викликає необхідність прогнозування, наскільки пандемія вплине на функціонування галузі, яку в найближчому майбутньому чекають зміни. Це стосується і календаря змагань, і спортивної економіки, i змагальних форматів.

Першою організацією, що повернулася на великі спортивні арени, став Абсолютний бійцівський чемпіонат (UFC), який провів турнір в американському місті Джексонвілл (штат Флорида) завдяки підтримці місцевої влади, а також президента США - Дональда Трампа. При цьому сам захід пройшов без глядачів, а спортсмени та інші учасники турніру щодня здавали медичні тести. Весь обслуговуючий персонал, а також представники місцевої атлетичної комісії і судді користувалися необхідними засобами захисту, а присутні в залі люди дотримувалися соціальної дистанції [21].

За інформацією американського кабельного каналу ESPN, всі учасники турніру, в тому числі журналісти, підписали угоду, згідно 3 якою UFC не нестиме відповідальність у разі подальшого виявлення у кого-небудь коронавіруса.

Першою 3 топ-чемпіонатів 3 футболу після паузи, пов'язаної 3 пандемією, відновилася німецька бундесліга. 3 травня стартували футбольні чемпіонати в Чехії, Данії, Польщі, Португалії та Сербії [18].

(C) Пангелова Н., Рубан В., Пангелов Б., 2021 
Що стосується хокею, то сезон NHL був поставлений на паузу 12 березня 2020 року. 26 травня 2020 року було оголошено, що в рамках «Плану відновлення сезону за Кубок Стенлі» продовжать боротьбу 24 команди. 6 липня 2020 року Національна хокейна ліга i профспілка гравців NHL оголосили про досягнення домовленості про протоколи третього (тренувальні табори) і четвертого (відновлення матчів) етапів відновлення сезону.

Що стосується безпосередньо господарки Ігор 2020, то влада Японії поступово відновлює роботу спортивних об'єктів. Однак, однією з умов було обмеження відвідування $з$ тим, щоб вона не перевищувала $50 \%$ від звичайного рівня. Матчі бейсбольної та футбольної ліг поновилися з 19 червня 2020 року. Глядачів на стадіони почали пускати 310 липня 2020 року, при обмеженні кількості уболівальників на 50\%. Був розроблений регламент для проведення спортивних змагань в умовах пандемії нового коронавіруса. Зокрема, організатори повинні вживати ряд заходів, що включають в себе: скорочення кількості місць на спортивних об'єктах, забезпечення дотримання соціальної дистанції між людьми. Працівники і глядачі повинні носити маски та користуватися антисептиками. Крім того, на входах можуть вимірювати температуру, а зони кас повинні бути затягнуті поліетиленовою плівкою. Також передбачається проводити постійний моніторинг стану здоров'я спортсменів.[4, 14].

Пандемія коронавіруса внесла істотні корективи в життя спортивної спільноти. Повсюдна ізоляція прискорила цифровізацію спортивного бізнесу i підштовхнула організаторів до реалізації проектів, заснованих на онлайнтехнологіях.

Як свідчать результати аналізу спеціальної літератури, цифрові технології активно впроваджу- ються як в професійний, так і в аматорський спорт, що мотивує громадян вести здоровий спосіб життя. Мобільні додатки стають невід'ємною частиною побуту i допомагають організувати режим дня, правильне харчування, ефективні індивідуальні тренування і багато іншого. Сучасне покоління, що володіє «цифровим мисленням», швидко освоює нові девайси і активно використовує їх для самовдосконалення. Передові технології дозволяють набагато ефективніше здійснювати збір, обробку та передачу інформації, якісно змінювати методи і організаційні форми підготовки висококваліфікованих спортсменів, тренерів та суддів, а також проведення фізкультурно-оздоровчої роботи 3 населенням. Цифрові технології широко використовуються компаніями, що займаються спортивною аналітикою, професійної статистикою, зйомкою матчів, скаутінгом і онлайн-трансляціями. 3 точки зору спорту, процес комунікації з уболівальниками, робота в медійному простоpi, формування нових цифрових продуктів навколо традиційних форматів - це той шлях, на якому зараз знаходяться найбільші світові клуби і федерації $[11,17]$.

В умовах кризи, яка виникла внаслідок пандемії COVID-19 стає особливо актуальною державна підтримка спортивної індустрії, яка опинилася в надзвичайно скрутному становищі. «Європейська платформа 3 інновацій в галузі спорту» визначила заходи, необхідні для підтримки спортивної індустрії в Європі [21]:

- Забезпечення спортивної індустрії фінансовими коштами, спрямованими на захист робочих місць, співробітників і самозайнятих від загрози звільнення i втрати доходу.

- Пом'якшення правил, що стосуються отримання державної допомоги, 3 метою надання податкових послаблень організа- ціям, що займаються розвитком спорту (подібно до того, як це реалізовано в інших галузях економіки).

- Стимулювання інноваційних програм для підприємств в сфері спорту з метою подолання існуючих соціальних викликів.

- Надання позик для забезпечення ліквідності спортивних клубів та інших асоціацій через існуючі фінансові інструменти (наприклад, «Європейський інвестиційний банк») або шляхом створення нових.

- Створення державних і приватних фондів солідарності для аматорських спортивних клубів i асоціацій та їх співробітників, включаючи зовнішніх тренерів i позаштатних працівників - самозайнятих осіб.

- Створення нових можливостей фінансування в якості інноваційних шляхів сприяння розвитку спорту і фізичної активності в період, коли люди обмежені в пересуванні.

- Надання допомоги школам i викладачам фізкультури для продовження навчання за допомогою ефективних i безпечних цифрових засобів.

Основна підтримка індустрії спорту визначається національними урядами. У той же час відбувається надання допомоги 3 боку спортивних організацій (федерацій, асоціацій та інших об'єднань), а також на національному рівні.

Крім фінансової підтримки, державні установи розробляють рекомендацї для спортивних організацій щодо діяльності в умовах поступового зняття обмежувальних заходів. Наприклад, уряд Великобританії розробив спеціальне керівництво «Повернення до тренувань в області спорту високих досягнень: перша стадія» (доступні також документи про другу і третю стадії). Керівництво повинно допомогти організаціям в сфері спорту високих досягнень забезпечити безпечне повернення 
до організованого тренувального процесу для спортсменів і персоналу 3 дотриманням принципів соціальної дистанції.

Якнайшвидшого відновлення звичного режиму проведення заходів чекають всі представники спортивної галузі: самі спортсмени, організатори змагань, вболівальники, телеканали, виробники спортивних товарів і багато інших. При цьому, експертні оцінки не дають однозначних прогнозів щодо термінів повноцінного відновлення спортивної сфери, однак дозволяють виділити кілька трендів, які мають високу ймовірність закріпитися в світі спорту як довготривалих наслідків пандемії COVID-19.

Одним 3 очевидних пріоритетів стане збереження і закріплення посилених заходів безпеки при проведенні масових спортивних заходів. Так, Організація Об'єднаних Націй (ОOH), визнаючи цінність спорту для здоров'я i благополуччя населення, а також його соціальну та економічну значущість, підготувала загальні рекомендації для урядів і міжнародних організацій, покликані забезпечити безпечне відновлення спортивних заходів по завершенні пандемії. Окрема увага приділяється необхідності збереження професійної спортивної екосистеми і налагодження комунікації з уболівальниками з метою роз'яснення запобіжних заходів і створення безпечних умов для відвідування майбутніх змагань.

Висновки. Аналіз умов функціонування сфери міжнародного спортивного та олімпійського рухів в умовах світової пандемії Covid-19 дозволив визначити такі основні тенденції:

- Сфера спорту і розваг все більше орієнтується на онлайнформати. Діючі в період карантину онлайн-практики продовжать діяти і після закінчення пандемії.

- Серед основних викликів у спортивній індустрії можна відзначити падіння доходів спортивних організацій, пропуск спортсменами цілого сезону, а також втрату фінансових вигод і можливості тренуватися і конкурувати, загострення проблеми безробіття.

- Глобальна вартість індустрії спорту оцінюється в 756 млрд. доларів в річному вираженні. Спорт представляє собою помітний сектор в економіці регіонів світу та окремих країн. Наприклад, в СС частка ВВП, пов'язана зі спортом, становить 279,7 млрд. євро, що еквівалентно 2,12\% від загального ВВП СС.

- За прогнозами, найбільш постраждалими виявляться основні ліги в США (Головна бейсбольна ліга (MLB), Вища ліга футболу (MLS), Національна хокейна ліга (NHL), Національна баскетбольна асоціація (NBA), Національна футбольна ліга (NFL), і в Свропі (Англійська прем'єр-ліга, іспанська La Liga; крикет, регбі та футбол в Великобританії, італійська Серія А, французька Ліга 1).

- Значні втрати пояснюються падінням доходів від продажу прав на трансляцію, комерційної діяльності та проведення матчів. Падіння доходів спортивних організацій негативно відбивається на положенні спортсменів (втрата роботи, зменшення заробітних плат).

- Основну підтримку індустрії спорту надають національні уряди. Робляться спроби сприяння з боку спортивних організацій, а також - на національному рівні.

- Експерти не очікують серйозних довгострокових наслідків пандемії COVID-19 в сфері організації та проведення міжнародних спортивних змагань за винятком вимушеного перенесення найближчих заходів.

- Одним $з$ очевидних пріоритетів в період після піку пандемії COVID-19 стане підвищена турбота про здоров'я спортсменів, глядачів і суспільства в цілому, а також закріплення посилених заходів безпеки, спрямованих на запобігання поширенню коронавирусной інфекції при проведенні масових заходів, включаючи вимоги за ступенем заповнюваності трибун і приміщень, використання засобів індивідуального захисту, проведення медичних оглядів та інших.

- Як і в багатьох інших сферах, вимушені зміни моделі економічної поведінки професійних учасників в період пандемії сприятимуть і подальшої трансформації їх діяльності. Однією з найбільш помітних змін, ймовірно, стане диверсифікація джерел доходів спортивних асоціацій за рахунок подальшого використання технологій віртуальної і доповненої реальності 3 метою створення $\mathrm{i}$ поширення контенту, створення нових інформаційних продуктів і встановлення прямої взаємодії 3 глядацькою аудиторією.

- Безпосередньо після пандемії можливе помітне зростання інтересу до сфери спорту в зв'язку 3 підвищеним попитом з боку уболівальників і підвищеною увагою громадян до стану свого здоров'я.

- Ігрова індустрія, включаючи кіберспорт і розробку ігор в умовах пандемії відчуває себе впевнено.

- Коронавірус в черговий раз підкреслив, що віртуальна реальність має ряд переваг, наприклад, в плані безпеки: у користувачів немає необхідності безпосередньо контактувати один 3 одним, вони можуть взаємодіяти, залишаючись на віддаленій відстані.

Конфлікт інтересів. Автори заявляють, що відсутній будьякий конфлікт інтересів.

Перспективи подальших досліджень - пов'язані з більш глибоким вивченням наслідків впливу пандеміï Covid-19 на подальший розвиток міжнародного спортивного руху та його складових. 


\section{Література}

1. Будущее за цифровой трансформацией спорта? URL: http://digitalrus.online/ (дата звернення 28.05.2021).

2. Булатова М.M. Енциклопедія олімпійського спорту в запитаннях і відповідях. Київ: Олімпійська література, 2014. 400 с.

3. В Совете $\mathrm{OOH}$ по правам человека принята резолюция «Поощрение прав человека через спорт и идеалы Олимпийского движения». Новости ОOH (un.org). URL: https://news.un.org/ (дата звернення 16.06.2021).

4. Виктор Рожков. В июне Япония поэтапно снимет ограничения на передвижение по стране. URL: https://traders-union.ru/ (дата звернення 28.05.2021).

5. Глава UFC рассказал о потере более $\$ 100$ млн из-за коронавируса. URL: https://iz.ru/ (дата звернення 15.05.2021).

6. Какие соревнования отменили из-за коронавиpyca: карантин в спорте. URL: https://www.sportexpress.ru/ (дата звернення 10.05.2021).

7. На конференции ЮНЕСКО в Берлине принят план действий по укреплению правопорядка в спорте и обеспечению его общедоступности (unesco.org). URL: https://ru.unesco.org/ (дата звернення 11.05.2021).

8. Платонов В. М. Система підготовки спортсменів в олімпійскому спорті. Київ: Олімпійська література, 2015. Кн. 2. 752 с.

9. Платонов В. Н., Гуськов С. И. Олимпийский спорт : Учебник (1-я книга). Киев: Олимпийская литература, 2014. 351 с.

10. Суник А.Б. Современные олимпийские игры: краткий исторический очерк (1896-2012 гг.) Москва. Советский спорт. 2013. 232 с.

11. Эмин Антонян. Спорт, который сильнее вируса: как спортивная индустрия переходит на онлайн-форматы. URL: https://www.forbes.ru/ (дата звернення 28.05.2021).

12. 25 років разом. Олімпійська освіта / [за заг. ред. С. Н. Бубки, М. М. Булатової]. Київ: 2017. 128 с.

13. ASOIF statement on the Tokyo 2020 Olympic Games. 25 Mar 2020. URL: https:/www.asoif. com/ (дата звернення 15.05.2021).

14. Canceling Tokyo Olympics would lower Japan GDP growth by $1.4 \%$ : estimate

15. Daniela Bas, Melissa Martin, Carol Pollack and Robert Venne. Division for Inclusive Social Development in UN DESA. For further information, contact undesa@un.org, or visit. URL: https:// www.un.org/development/desa/publications/ (дата звернення 10.05.2021).

16. Joint Statement from the International Olympic Committee and the Tokyo 2020 Organising Committee - Olympic News (olympics. com).

\section{References}

1. The future behind the digital transformation of sports? URL: http://digitalrus.online/ (accessed 28.05.2021).

2. Bulatova M.M. Encyclopedia of Olympic sports in questions and answers. Kyiv: Olympic Literature, 2014. $400 \mathrm{p}$.

3. The UN Human Rights Council, adopted a resolution "Promoting human rights through sport and the ideals of the Olympic Movement." UN News (un.org). URL: https://news.un.org/ (accessed 16.06.2021).

4. Victor Rozhkov. In June, Japan will gradually lift restrictions on travel around the country. URL: https://traders-union.ru/ (access date 28.05.2021).

5. The head of the UFC spoke about the loss of more than $\$ 100$ million due to the coronavirus. URL: https://iz.ru/ (date of the beast 15.05.2021).

6. What competitions were canceled due to the coronavirus: quarantine in sports. URL: https:// www.sport-express.ru/ (access date 10.05.2021).

7. The UNESCO Conference in Berlin adopted an action plan to strengthen law and order in sport and ensure its public access (unesco.org). URL: https:// ru.unesco.org/ (access date 11.05.2021).

8. Platonov V.M. The system of training athletes in Olympic sports. Kyiv: Olympic Literature, 2015. Book. 2. $752 \mathrm{~s}$.

9. Platonov V.N., Guskov S.I. Olympic sport: Textbook (1st book). Kiev: Olympic Literature, 2014. $351 \mathrm{p}$.

10. Sunik A.B. Modern Olympic Games: a brief historical essay (1896-2012) Moscow. Soviet sport. 2013. 232 p.

11. Emin Antonyan. Sports that are stronger than the virus: how the sports industry is moving to online formats. URL: https://www.forbes.ru/ (access date 28.05.2021).

12. 25 years together. Olympic education / [for general. ed. SN Bubka, MM Bulatova]. Kyiv: 2017. 128 p.ASOIF statement on the Tokyo 2020 Olympic Games. 25 Mar 2020. URL: https:/www.asoif. $\mathrm{com} /$ (date of application 15.05.2021).

13. ASOIF statement on the Tokyo 2020 Olympic Games. 25 Mar 2020. URL: https:/www.asoif. $\mathrm{com} /$ (date of application 15.05.2021).

14. Canceling Tokyo Olympics would lower Japan GDP growth by $1.4 \%$ : estimate

15. Daniela Bas, Melissa Martin, Carol Pollack and Robert Venne. Division for Inclusive Social Development in UN DESA. For further information, contact undesa@un.org, or visit. URL: https:// www.un.org/development/desa/publications/ (date of application 10.05.2021).

16. Joint Statement from the International Olympic Committee and the Tokyo 2020 Organising

(C) Пангелова Н., Рубан В.,

Пангелов Б., 2021 
URL: https://olympics.com/ (дата звернення 15.05.2021).

17. Position paper on the impact of the Covid-19 crisis on the sport sector. URL: https://epsi.eu/ (дата звернення 10.05.2021).

18. Potential maximum revenue loss of European football leagues due to the coronavirus (COVID-19) in the season 2019/2020, by source. URL: https:// www.statista.com/ (дата звернення 10.05.2021).

19. Sports leagues will lose at least $\$ 12 \mathrm{~B}$ in revenue due to stoppages cause by COVID-19 pandemic: report. URL: https://www.cbssports.com/ (дата звернення 10.05.2021).

20. The Economic Impact of Covid-19 on US Sports. URL: https://economicmodeling.com/ (дата звернення 10.05.2021).

21. The impact of COVID-19 on sport, physical activity and well-being and its effects on social development. POLICY BRIEF N 73. May 2020. S. 1-4. URL: https://www.un.org/ (дата звернення 10.05.2021).

22. URL: https://english.kyodonews.net/ (дата звернення 15.05.2021).

\section{Пангелова Наталія}

Університет Григорія Сковороди в Переяславі

м. Переяслав, вул. Сухомлинського 30, 08400, Україна

e-mail: kafeda.tmfvis@ukr.net, тел. 380979227234

ORCID https://orcid.org/0000-0002-4846-3907

\section{Рубан Владислав}

Університет Григорія Сковороди в Переяславі

м. Переяслав, вул. Сухомлинського 30, 08400, Україна e-mail: ruban.vlad1991@ukr.net, тел. 380634957230

Пангелов Борис

Університет Григорія Сковороди в Переяславі

м. Переяслав, вул. Сухомлинського 30, 08400, Україна
Committee - Olympic News (olympics. com). URL: https://olympics.com/ (date of application 15.05.2021).

17. Position paper on the impact of the Covid-19 crisis on the sport sector. URL: https://epsi.eu/ (date of application 10.05.2021).

18. Potential maximum revenue loss of European football leagues due to the coronavirus (COVID-19) in the season 2019/2020, by source. URL: https:// www.statista.com/ (date of application 10.05.2021).

19. Sports leagues will lose at least $\$ 12 B$ in revenue due to stoppages cause by COVID-19 pandemic: report. URL: https://www.cbssports.com/ (date of application 10.05.2021).

20. The Economic Impact of Covid-19 on US Sports. URL: https://economicmodeling.com/ (date of application 10.05.2021).

21. The impact of COVID-19 on sport, physical activity and well-being and its effects on social development. POLICY BRIEF N 73. May 2020. S. 1-4. URL: https://www.un.org/ (date of application 10.05.2021).

22. URL: https://english.kyodonews.net/ (date of application 15.05.2021). 